Int. J.Morphol.,

25(4):671-676, 2007.

\title{
Scientific Plagiarism, is Also Present in the Morphological Sciences
}

\author{
Mariano del Sol
}

Each time there are more ethical violations in scientific publications that even reach basic disciplines such as morphological publications some of which have affected our journal.

Initially my intent was to try only one sensitive issue, protagonized by investigators of the university of the Middle East (Egypt and Saudi Arabia) that involved work published in the Egyptian Journal of Histology and the International Journal of Morphology. However, I will also address other issues related with scientific plagiarism, two of which directly affected the Revista Chilena de Anatomía (Chilean Anatomical Journal), Revista Médica de Chile, Odontólogo Moderno and the International Journal of Morphology.

Some scientific journals deal with scientific plagiarism as a mere ethical violations that affects a part of the publication process, including these ethical violations, not only of fictitious and unjustified papers, but also including those duplicate and fragmented publications, and including those where there is invention, falsification and/or malicious manipulations of the information. However I believe, as do others that scientific plagiarism is not an ethical violation, rather it constitutes scientific fraud. The Dictionary of the Spanish Language (RAE, 2007) defines it as the "copy of the substantial portion of foreign work, publishing it as ones own".

There is no agreement among scientists as far as the outreach and number of scientific plagiarism or if these have increased in the past years, however suffice to say that by reviewing Internet it is clearly effective that this type of fraud is present in all areas of knowledge and information, from literature to theoretical physics. In regard to the latter and as an example, the impressive case of a group of students of the University of Ankara (Turkey), who were able to publish over 40 articles in journals, in only 22 months without being detected by the editorial bodies of the journal, despite all of the articles being extracted from others published by specialists. This scientific theft was discovered by professors of the Masters Program that these students were involved in by the Rector of the University of Ankara who requested that said articles be withdrawn from the Journal of High Energy Physics.
As mentioned by Rodríguez (2006) he frauds and plagiarisms are not new to science. In agreement with him I consider that Internet is a marvelous as well as a terrible tool, responsible for the rapid growth and development of academic plagiarism (cyber plagiarism or digital plagiarism). 1 However, scientific plagiarists have always existed, as is demonstrated in the article published by Silva et al. (2007) who point out that one of the first expressions of plagiarism in Cuba, occurred in 1873 where plagiarism was reported in a Memory realized by the scientist Carlos Finlay Barres.

For some time the ethical aspects of scientific investigation and especially in publications of this type, have been a concern to Editors and the respective Scientific Committees of the journals. It was exponentially a concern when the South Korean researchers Woo-Suk Hwang published in Science 303(5664):1669-1674, 2004 and Science, 308(5729):1777-1783, 2005) the cloning of human embryos and the obtaining of stem cells, which was later proven had manipulated the information and all was a scientific fraud.

It appears that scientific plagiarism have increased in the past, or perhaps this might be because they are more easily detectable, be it for the existence of Internet or due to the lesser capacity and intelligence of plagiarists. As one reviews Internet there are hundreds of reported cases noting the scientific mal praxis.

The El Mundo (2005) newspaper reported in its headline "A US astronomer accuses a Spanish colleague of scientific plagiarism". In another editorial of the journal " $R e$ vista Médica de Uruguay", Rodríguez writes regarding plagiarism and frauds in the era of globalization, pointing out that Internet offers plagiarism many advantages, among them, the possibility of a grater impunity. Although I do not agree with that pointed out in regard to impunity, I am with the affirmation that for researchers, editors and reviewers, it is practically impossible to detect plagiarisms under any circumstance currently and highly improbable to detect if plagiarism comes from the Internet. 
In reference as to why scientists and investigators make use of plagiarism the explanations are endless, from feeling valued, recognized in their work, up too obtaining a curriculum that allows them to reach academic hierarchy, and in consequence an improvement in the social and academic status and salary. Of course all justifications for this type of action are unacceptable and all these fraudulent acts should be reported to the respective authorities who have the obligations to take the necessary steps in order that this type of occurrence are not repeated.

In Perú, the efforts made by the Editing Committee of the journal "Ciencias e Investigación Médica Estudiantil Latinoamericana" are notable, with the creation of a detection and management system of plagiarism cases which has rendered excellent results (Rojas-Revoredo et al., 2007). An article was withdrawn from print and the review process of others was detained. The reviews were supported by the flow gram of the work of the Ethics Publications Committee. (www.publicationethics.org.uk). The Journal created this system of review a product of plagiarism reported by Cabrera et al. (2007).

In a recent editorial, Martin (2007) refers to the concern that exists regarding the possible increaser of plagiarism in Social Sciences. This concern reaches the actors involved in the scientific publications. Recently Silva et al. motivated by the reports o scientific ethic that affected two Cuban publications, who wrote an excellent article of review regarding the improper reports of scientific publications.

As was mentioned at the beginning of this presentation, I will deal with three cases of scientific ethics, who of the affected the International Journal of Morphology and another affected its predecessor the Chilean Journal of Anatomy.

The first case took place in the year 2005, when an article published in the Chilean Anatomical Journal (Rev. Chil. Anat., 13(1):33-42, 1995.), was sent by the first author to two Journals ISI one Chilean and one Brazilian. The journal Revista Médica de Chile published the article (Rev. Med. Chile, 124(4):417-21, 1996.) which corresponds to a part of the original, identical in its editorial and images. It dealt with the same article with a different title, in which the authors had been eliminated including the other, thus constituting a scientific fraud.

According to the Editorial of the Revista Médica de Chile "the comparison of both publications allowed the Editor to prove that the articled published in the Chilean Anatomical Journal included a morphometric analysis that does not appear subsequently published in the Revista Médica de Chile." However, the Revista Médica de Chile in its Editorial treated it as a redundant publication (Reyes, 2007), appreciation that I have never shared, as I consider it to be incorrect.

The same article was attempted to be published in the
Brazilian Journal of Medical and Biological Research. For said Journal the article had been translated to English, the title had been changed including two authors, none of whom appeared in the first publication, in addition to having eliminated the last four authors of the original work. Once the ethical problem was detected the Journal demanded explanations of the authors and in view of not obtaining a satisfactory response and proving that it was a fact of plagiarism, rejected (copy of the process sent). Therefore, it was a case of scientific fraud. All of the above gave way for the Editor of the Chilean Anatomical Journal(del Sol, 1996) would expose in detail the grave ethical violation committed by the first author of the two articles.

I wish to clarify that the ethical problem was caused only by the first author, as the other authors (Brazilian) of the first publication sent numerous letters to the Editor of the Chilean Anatomical Journal explaining the facts and requesting the immediate withdrawal of their names. They did not wish to be part of an issue of this nature.

In order to finalize this first case, I resume the sequential manner, of what occurred: the work was sent to the Chilean Anatomical Journal with a title and five authors. Subsequently the main author of the article sent it to the Brazilian Journal of Medical and Biological Research, with a different title and two authors, none of which appeared in the first publication. Finally the first author sent the work to the Revista Médica de Chile, again changed the title and the authors, excluding all of the remaining authors of the first publication and including one new author. Judge for yourselves: is it a scientific fraud or a redundant publication as was categorized by the Editorial of the Revista Médica de Chile? (Reyes, 1997).

In a new Editorial of the Revista Médica de Chile (Reyes, 2007), it is pointed out that in 1997 a redundant publication was detected whose facts were communicated to the respective university authority and to the readers of the Journal". As in the majority of the cases nothing ever happened. Of course the university summary was diluted in time.

The second case also dealt with an ethical violation, this one being less evident due to the languages used. A review article published in the International Journal of Morphology, (23(2):141-156, 2005) was plagiarized by in some paragraphs by a professor who translated the article from English to Spanish and published it in the Mexican journal Odontólogo Moderno (2(16) November, 2005). Through the Email the author notified the Editor of the situation by which he was affected, there was however no response. The paradox of the case is that the article written by the Colombian authors in the International Journal of Morphology was written in English and was translated to Spanish by a Professor of the Harvard Oral Medicine of the School of Mental Medicine, Boston Massachusetts and fragments of this work were published without mentioning the source in the Mexican journal. 
Currently the article is not available on the Internet as the entire edition was withdrawn from the journal Odontólogo Moderno.

Finally the third case of scientific fraud, perhaps the most complex due to its genesis and which has still not been fully clarified, was published when on June 10 of 2007 (13:19 h), I received an e-mail from Prof. Ahmed Said Elmorsy, Editor in Chief of the Egyptian Journal of Histology, who informed me that the article entitled "Age related changes in the urinary bladder of the female albino rats", published in the International Journal of Morphology 23(4):309-316, 2005, was taken from the Egyptian Journal of Histology $27(2$ December):402-416, 2004. The Editor mentioned that the articles were identical and that he had all originals of the article, including the microscopic slides. He demanded that I announce in the following edition of our Journal the situation that had occurred with the article and in addition, reserved all legal rights to establish some type of action regarding this type of plagiarism. I have never received the opinion of the authors Hoda M. Mahmoud, Seham H. Refaat, Iman H. Abdel-Aal, and Fardous Z. Saudy with respect to the article.

On the same day June 10, 2007 (06:21 h) Dr. M A Al Motabagani, Chairman and Head, Department of Anatomy, College of Medicine King Faisal University, Dammam, Saudi Arabia sent me an e-mail in which he expressed his desire to withdraw the article "Age-related changes in the urinary bladder of the female albino rats", published in he International Journal of Morphology, 23(4):309-316, 2005 and once the article had been withdrawn from the web, he was willing to cover any costs involved.

On June 13, 2007 I sent an e-mail replay to Prof. Ahmed Said Elmorsy in which I stated "It is my duty to communicate that up to this date I do no have in my possession the article that appears in your Journal. However the problem that has arisen with this publication is still not clear. I do no know if it is plagiarism or a duplicated publication". I also informed him that Dr. M A Al-Motabagani sent the original article by (DHL) mail and also communicated this by email on June 28th 2005". I sent said document as an attachment to Prof. Ahmed Said Elmorsy.

Up to that time I believed that Dr. M A Al-Motabagani had published in both journals, (I only had the e-mail sent by Prof. Ahmed Said Elmorsy), and thus communicated to him, "Clearly Dr. Motabagani did not inform either of the two journals regarding his intention to publish his article again, since he sent the article to the International Journal of Morphology several months after having published in your journal".

On August 19, 2007, Prof. Ahmed Said Elmorsy communicated that he was expecting the withdrawal of the article from our Journal, after having sent, in pdf format, the article cited published in the Egyptian Journal of Histology. 1 on August 25th of 2007 I informed Prof. Ahmed Said Elmorsy: "In reference to your email regarding the withdrawal of the article in the International Journal of Morphology, I must clarify that it is not possible to do so, as the Journal circulates in printed and on-line format, which must be identical. "What we are able to do however, is to include in issue 4 volume 25, 2007 an editorial in which the difficulties that arise with this type of publication will be discussed."

Due to the fact that there has not been much clarification regarding the events, namely with the different version of Dr. Motabagani, I requested Prof. Ahmed Said Elmorsy on August 24, (with copy to Dr. Motabagani) to reply to the following inquiries: "Where is the Egyptian Journal of Histology indexed? Are the photographs of the duplicate publication published, in color in The Egyptian Journal of Histology? When comparing the images of both articles in both journals, those that appear in the International journal of Morphology present greater detail and information. How could this be explained? This information is necessary in order to clarify the facts". I have received no reply to any of these inquiries.

At the same time, I requested explanations from Dr. Motabagani in an Email that stated: "I musty hereby inform you that as you have not rendered any explanation (except your request to withdraw the article) entitled "Age-Related Changes in the Urinary Bladder of the Female Albino Rats" which was published in your Journal Vol. 23 (4):309-316, 2005, which had previously been published in the Egyptian Journal of Histology, 27(2), 2004 by Hoda M. Mahmoud, Seham H. Fefaat, Iman H. Abdel-Aal \& Fardous Z Saudy of the Dept. of Anatomy, Faculty of Medicine fo the Ain Shams University Egypt.

We believe this is an extremely grave issue, particularly as it is an ethical issue and which must be clarified by the scientific community, and especially by yourself. Therefore, we need the following information:

1. Do you in effect admit to having copied the article from the Egyptian Journal of Histology and sending it to the International Journal of Morphology?

2. Should the above be true, would you be willing to publicly apologize sending us an email and stating the reasons?

3. The images in the Egyptian Journal of Morphology are published in black and white. How is it that you sent the same images in color? Should we not receive a satisfactory response we shall be obliged to contact the highest authorities of the King Faisal University. Finally I must hereby remind you that you have not paid the costs of the article published 24(3):417422, 2006, which also constitutes a problem."

Dr. Motabagani replied on August 27, 2007 (he sent the same Email on 8-28-07 and 9-12-07) and expressed his appreciation for maintaining him informed of the 
correspondence established between this Editor and Prof. Ahmed Said El-Morsy, related to the duplicate article. Dr. Motabagani explained why he wanted to withdraw the article from the International Journal of Morphology. The following is the explanation given by Dr. Motabagani:

"Dear Professor Mariano del Sol. Thank you for your e-mail dated Aug. 24th, 2007 and for keeping me informed of the correspondence between you and Professor Ahmed ElMorsy, the Chief Editor of the Egyptian Journal of Histology, regarding the above article. I would like to explain why I wish to withdraw the article from you esteemed Journal.

In 2004, I had an agreement with an know Senior Egyptian Professor to do joint research work on the Urinary bladder. I was responsible for the practical work and he was responsible for writing the manuscript. Accordingly I carried out and completed the practical work on the urinary bladder of the newborn, one-month-old adult (3-months-old) and senile (24-months-old) albino rats. I photographed many histological sections and sent to my research fellow 8 strip films containing more than 200 coloured images. Each film role was labeled according to the age of the animal. Also I sent him copies of reference articles which I obtained from internet search. He printed the strip-films in Egypt and sent me the manuscript together with the coloured images.

When I reviewed the article the only thing I noted was that the images contained prints from Scanning Electron Microscope, which I did not forward to him. I phoned him and confirmed that this was a contribution to the article. Also he informed me that he did not wish to have his name as a coauthor simply because he has been a Senior Professor for a long time and does not need any publications. As a result I sent the article to your Journal as a single author.

In June 2007, I was contacted from Egypt by a Chairperson and a previous colleague in my department, named Professor Eman El-Nashar. She informed me that Professor Ahmed El-Morsy, the Chief Editor of the Egyptian Journal of Histology has told her that the article which I published in the International Journal of Morphology in 2005 was copied from an article published in his journal in 2004.

I was very concerned. Hence I traveled to Cairo (Egypt) on the 20th June 2007, to see for myself the Egyptian article. I met Prof. El-Morsy who allowed me to glance briefly at the article in a reprint in black and white. I informed Prof. El-Morsy that I never saw that Egyptian article before and that I have done the practical work on the urinary bladder and explained to him all the above.

Prof. El-Morsy asked me to send him examples of the images which I have produced from my own work immediately after my return to Saudi Arabia, to prove that I have done the work. Immediately after my return to Saudi I sent to Prof. El-
Morsy a parcel by DHL which he received few days later, containing the following:

1. Examples of photomicrographs of sections of the urinary bladder of newborn albino rats

2. Examples of photomicrographs of sections of the urinary bladder of one-month-old female albino rats

3. Examples of photomicrographs of sections of the urinary bladder of adult (3-months-old) female albino rats

4. Examples of photomicrographs of sections of the urinary bladder of senile (24-months-old) female albino rats; each image was accompanied by its description

5. Copies of reference articles which I have obtained via internet search during my practical work, showing the date of the search (2004).

Once again I traveled to Egypt on the 25th July 2007 to meet with Prof. El-Morsy to finalize the situation. He informed me that he sympathizes with me and that I have been misguided by my research fellow.

I met with my research fellow, who has joined my department as a Senior Faculty, and informed him of the dilemma he put me in. He stated that the article must have been sent to him as an assessor; and that he sent it to me (in 2004) by mistake thinking that it was mine. I was very disappointed by that statement. He requested me to terminate his contract, and he left Saudi Arabia and returned to Egypt in July 2007. Prof. El-Morsy knows the name of my research fellow, his position and place of work.

Finally, I would like to stress that:

1. I did not know about or see the article published in the Egyptian Journal of Histology before I met Prof. El-Morsy in June 2007, and that I did not know that the manuscript given to me by my research fellow was from a published article.

2. the published articles in that Egyptian Journal are only produced as reprints to the authors

3. the Journal was not produced in an authenticated form, i.e., a complete volume in form of a book containing number of articles, that can be circulated and referred to

4. the articles (and even the titles of the articles) in that Egyptian Journal are not available on the internet

5.the Egyptian Journal has no website

Dear Professor Mariano del Sol. These are the facts before you. I feel very bad about what has happened, and I wish to apologize to you and to your Journal. Because I accepted not to include the name of my research fellow as a co-author I take the responsibility of withdrawing the article and to cover the cost of its withdrawal.

Thank you for your understanding my situation and I hope that the above clarifies it. Best regards. Yours truly, Dr. M A Al-Motabagani Chairman \& Head, Department of Anatomy, College of Medicine King Faisal University" 
On September 23, 2007 in an e-mail Prof. Ahmed Said Elmorsy, (in response to my e-mail of August 24th 2007) points out the following:

"Dr. Mariano del Sol. When I received your last email, I was extremely astonished with your response. It seems that you forgot the details of the event:

1-I told you that this original article belongs to four staff members in the anatomy department-Ain shams University. 2-I have all the originals including the microscopical slides of this work.

3-Dr. M. A. Al-Motabakani wrote to you asking for the withdrawal of the article and I received a copy from his email.

4- I tried to avoid using tough words but I am obliged to tell you that this is a case of dishonesty-plagiarism-theft of a scientific work and you can choose what suits you.

5-A copy from the original paper together with the original coloured photomicrographs have been handled some how to Dr. Motabakani (I know all the details of how he received them).

So, I am emphasizing once more the seriousness of this event reserving all the rights of the original authors and our journal against all who participated in this event including your journal. This is because of your refusal to take the correct action to resolve this problem.

Dr. Motabakani told me, lately, that he wrote to you to clarify his position but he never denied the real situation. He admitted that he received the original article and original colored photomicrographs from some one (I know that person).

So, with regard to all what I mentioned and all the data at my hands, I hope that you will proceed to correct all what happened by declaring in your journal (next issue) the withdrawal of this article and sending to me a copy from that declaration. I hope that I will not wait longer.

$N$. B. Since I received the complaint of the original authors I guessed how this could happen. What really happened was within the range of this guessing."

Subsequently on September 26th I replied to Prof. Ahmed Said Elmorsy in the following terms:

"Dear Dr. ElMorsy. In reference to your last email, I am also extremely surprised. I would like you to take note of what I have discovered up to this moment:

$1^{\circ}$ As you know, the fact that the article had been previously published in the Egyptian Journal of Histology, was not detected by the evaluators of the Int. J. of Morphology. In order to obtain some sort of explanation I requested you indicate where your journal is indexed, as it does not appear in any international index, thus it is very difficult to know whether an article has already been included in another journal. You did not respond to my query.

$2^{\circ}$ I have all of the originals in color of all of the figures of the article, including their numbers and indications of the highest quality.

$3^{\circ}$ Dr. M. A. Al-Motabakani's version who has written me several times, is absolutely different from that which you mention in your email.

$4^{\circ}$ According to Dr. M. A. Al-Motabakani, he realized all of the experimental part in Saudi Arabia, and that the article was written by a Professor invitedby him. This Senior Professor subsequently returned to Egypt.

$\neq 5^{\circ}$ Dr. M. A. Al-Motabakani, mentions that he traveled to Egypt twice in order to clarify the problem, and that he was only shown a photocopy of the article.

$\sigma^{\circ}$ Undoubtedly, the publication in the Int. J. Morphology, of the article by Dr. M. A. Al-Motabakani is absolutely incorrect, and falls under the denominated plagiarism, which will be clarified as I already mentioned in the issue no.4, volume 25, year 2007.

7. Yourself as well as R. M.A. Al-Motabakani, are requesting that the article be withdrawn, which is impossible since the Journal circulates in paper format and Online, and both must be identical. I As you will understand to withdraw or request the return of all copies distributed throughout the world is absolutely impossible.

$8^{\circ}$ I must remind you that I have not forgotten the details of the event and you may take all the steps you deem necessary. In order to clarify this matter we have in fact used most proper judgment.

$9^{\circ}$ Finally I wish to express that your inadequate threatening attitude toward our Journal which is being damaged by academics of the Anatomy Departments of Ain shams University and King Faisal University, who due to personal problems have incurred in an ethical error, is not correct. $10^{\circ}$ Once the problem is addressed in issue no. 4 of the Int. J. of Morphology, I will send you a copy. I need your postal mailing address".

Finally on November 9, 2007 Prof. Ahmed Said Elmorsy replied: "We should cooperate to condemn plagiarism and protect authors rights."

I most definitely agree with Prof. Ahmed Said Elmorsy, however, I am still in doubt regarding the real facts that occurred with this duplicated and plagiarized publication. As has been noted, both publications only differ in the phrase of the chapter of Material and Method for the authors Hoda M. Mahmoud, Seham H. Refaat, Iman H. Abdel-Aal and Fardous Z. Saudy, the rats were obtained from the animal house of the Medical Research Center, Ain Shams University, Egypt; on the other hand as Mohamed Akram Al-Motabagani the rats were obtained from the animal house, College of Medicine, King Faisal University, Dammam, Saudi Arabia. 
In this extensive and detailed report I have wanted to expose a real problem that involves scientific journals. I insist that this ethical problems that gravely affect the credibility of research are very difficult to detect and control. There are no certain formulas. The review by peers more than to detect a plagiarism or scientific fraud, allows the review of the quality of the work and the importance for its publication in a determined journal. The evaluator is not a detective on the look out of a scientific theft, and when fraud is discovered, it almost always occurs at random.

As has been mentioned, Internet is a tool that allows the detection of issues that escape ethical standards that should be included and cultivated in the Sciences. The fact that the International Journal of Morphology is indexed, is in place of important data bases and is in addition, on open access, and accessible through any search engine, has allowed us to detect grave ethical violations.

In an interesting article of Benach de Rovira \& Tapia Granados (1996) and commenting on the book "Traitors of the truth", it is pointed out that the book was a blow to scientific mythology. "Its authors manifested that scientists are part of society, that they are no different from the rest of the population as far as honesty concerns, and that in their work as in the work of others, conflicts of interests, prejudices and ambition have an influence." These interesting phrases state what is currently taking place in the scientific community, particularly the academic university community, pressured by the need to publish, regardless of the means. Goals must be met and how it is achieved appears to become a secondary issue for some.

As has been pointed out in an editorial of the British Journal of Industrial Medicine, scientific mal praxis covers a full spectrum, where at the inferior extreme the duplicated publication is situated, and at the superior extreme, fraud and plagiarism are found. The latter and the most grave and which unfortunately has affected morphologists in the above mentioned cases.

I believe that one of the fundamental aspects that affects scientific mal praxis, is the lack of a true ethical education which scientists ought to have, as it happens, without such a base it is very probable they derive in plagiarism, an embarrassing and very grave act of intellectual dishonesty.

As the Editor of the International Journal of Morphology I wish to declare my profound annoyance and rejection of the events having taken place.

The procedure will be to withdraw the article online published in the International Journal of Morphology, 23 (4):309-316, 2005, for constituting scientific plagiarism. Samples of this abstract shall be sent to those affected.

\section{REFERENCES}

Al-Motabagani, M. A. Age-related changes in the urinary bladder of the female albino rats. Int. J. Morphol., 23(4):309-316, 2005.

Benach de Rovira, J. \& Tapia Granados, J. A. Mitos o realidades: a propósito de la publicación de trabajos científicos. ACIMED, 4(1):41-6, 1996. (Condensado por Cáceres Manso E y Cañedo Andalia R).

Cabrera, R.; Mayo, C.; Suárez, N.; Infante, C. Náquira, C. \& García Zapata, M. Plagio en un artículo estudiantil. Ciencia Médica Estudiantil Latinoamericana (CIMEL), 12(1):32-3, 2007.

Del Sol, M. ¿Es ético no informar faltas a la ética científica?. Rev. Chil. Anat., 14(2):101, 1996.

Díaz, A. Un astrónomo de EEUU acusa a un colega español de plagio científico. El mundo, XVII (5756), 15 septiembre de 2005.

Hoda M. Mahmoud; Seham H. Refaat; Iman H. Abdel-Aal \& Fardous Z. Saudy. Age-related changes in the urinary bladder of the female albino rats. Egypt. J. Histol., 27(2):402-416, 2004.

Martin, B. R. Keeping plagiarism at bay-A salutary tale. Research Policy, 36(7), September: 905-11, 2007.

Ramírez, A. L. M.; Sandoval, O. G. P. \& Ballesteros, L. E. Theories on otic symtoms in temporomandibular disorders: Past and Present. Int. J. Morphol., 23(2):141-56, 2005.

Real Academia Española. RAE. Diccionario de la Lengua Española. $22^{\mathrm{a}}$ ed. 2007 . http://buscon.rae.es/draeI/SrvltConsulta? TIPO_BUS $=3 \&$ LEMA $=$ plagio

Reyes, H. Una publicación redundante en la Revista Médica de Chile. Rev. Méd. Chile, 125:956-7, 1997.

Reyes, H. Ética de las publicaciones en revistas médicas. Rev. Méd. Chile, 135(4):529-33, 2007.

Rodríguez, Q. A. Plagios y fraudes en la era de la globalización. Rev. Méd. Urug., 22(2):83-6, 2006.

Rojas-Revoredo, V.; Huamaní, C. \& Mayta-Tristán, P. Plagio en publicaciones científicas en el pregrado. Experiencias y recomendaciones. Rev. Méd. Chile, 135(8):1087-8, 2207.

Silva, H. D.; Llanes, C. R. \& Rodríguez, S. A. Manifestaciones impropias en la publicación científica. Rev. Cub. Salud Pública, 33(4): 2007.

Sook-Bin-Woo. Síntomas óticos y desórdenes temporomandibulares. Odontólogo Moderno, 2(16), 2005. 